INTEGRITAS : Jurnal Pengabdian

Vol 4, No 1, Juli 2020

ISSN $2580-7978$ (cetak) ISSN 2615 - 0794 (online)

\title{
EDUKASI LITERASI KEUANGAN BAGI MAHASISWA DI KOTA PALEMBANG
}

\section{EDUCATION OF FINANCIAL LITERACY FOR STUDENTS IN PALEMBANG}

\author{
Budi Setiawan \\ Manajemen Keuangan, Fakultas Ekonomi, Universitas Indo Global Mandiri \\ Email: budi.setiawan@uigm.ac.id
}

\begin{abstract}
Abstrak: Literasi keuangan memiliki kontribusi penting tidak hanya bagi pelaku bisnis tapi juga untuk semua kalangan masyarakat. Masyarakat dengan tingkat literasi keuangan yang tinggi akan menerka dampak minimal saat terjadi krisis keuangan. Selain itu, tingkat literasi keuangan yang tinggi memberikan informasi penting agar dapat menjangkau berbagai sumber pendanaan dan juga informasi seputar instrumen keuangan di Indonesia. Instrumen investasi di sektor keuangan ini menjadi penting karena dapat memberikan manfaat bagi banyak pihak, baik pemerintah maupun masyarakat. Investasi yang meningkat mampu mendorong ekspansi usaha dan menciptakan lapangan kerja, serta pendorong pertumbuhan ekonomi. Bagi masyarakat, pemahaman tentang investasi memberikan ruang alternatif agar uang mereka bisa bertumbuh setiap waktu. Mahasiswa merupakan generasi muda yang akan menjadi aset masa depan bangsa dan perlu memiliki pengetahuan seputar literasi keuangan agar mereka bisa mengambil keputusan keuangan dengan tepat.
\end{abstract}

Kata Kunci: Literasi Keuangan, Manajemen Keuangan, Mahasiswa

Abstract: Financial literacy has a significant contribution not only for business people but also for all people. An understanding of financial literacy will have a less negative impact due to the financial crisis. Besides, a high level of financial literacy provides essential information to be able to reach various funding sources and also information about financial instruments in Indonesia. Investment instruments in the financial sector are crucial because they can benefit many parties, both government and society. Increasing investment can encourage business expansion and create job opportunities and drive economic growth. For the community, an understanding of financial literacy provides an alternative so that they can manage money. Students are the young generation who will become the nation's future assets and need to know financial literacy so that they can make financial decision effectively.

Keywords: Financial Literacy, Financial Management, College Students 
INTEGRITAS : Jurnal Pengabdian

Vol 4, No 1, Juli 2020

ISSN $2580-7978$ (cetak) ISSN 2615 - 0794 (online)

\section{PENDAHULUAN}

Pendidikan menjadi salah satu fundamental yang sangat penting bagi perkembangan suatu negara. Selain itu, proses belajar di universitas akan meningkatkan kualitas hidup dan mendorong agar seorang individu mendapatkan manfaat sosial di masyarakat (Ozturk, 2008). Mahasiswa sebagai salah satu elemen penting dari sebuat universitas perlu mempelajari banyak hal, termasuk tentang literasi keuangan. Literasi keuangan tidak hanya penting bagi mahasiswa ekonomi dan manajemen keuangan, tapi juga bagi semua mahasiswa karena setelah mereka menyelesaikan pendidikan, pasti mereka akan mengambil keputusan-keputusan keuangan yang akan memberikan dampak pada kondisi keuangan mereka di masa depan. Selain itu, penelitian yang dilakukan oleh Klapper et al (2013) menjelaskan bahwa individu dengan tingkat literasi keuangan lebih tinggi akan terkena dampak negatif lebih rendah saat terjadi krisis di sektor keuangan.

Menurut Oseifuah et al (2018) menjelaskan bahwa literasi keuangan merupakan satu keahlian penting yang memiliki dampak signifikan terhadap individu, keluarga, dan juga ekonomi. Lebih jauh, pengetahuan keuangan akan berkontribusi positif terhadap proses mengambil keputusan keuangan yang lebih baik. Hal ini memiliki dampak yang positif, tidak hanya bagi rumah tangga tetapi juga bagi stabilitas keuangan dan ekonomi suatu negara (Lusardi, 2019). Sedangkan bagi mahasiwa, mahasiswa yang memiliki pengetahuan tentang literasi keuangan akan memiliki tabungan lebih banyak dibandingkan mahasiswa dengan tingkat literasi keuangan yang rendah. Tingginya tingkat literasi keuangan akan membuat mahasiswa lebih hati-hati dalam menggunakan kartu kredit dan mampu mencengah terjadinya masalah keuangan (Wann, 2016).

Berdasarkan hasil survey tingkat literasi keuangan pada lebih dari 500 mahasiwa di kota Palembang. Mahasiwa yang mampu menjawab pertanyaan seputar inflasi sebesar 60 persen. Sedangkan jawaban yang benar untuk pertanyaan seputar suku bunga dan diversifikasi risiko masing-masing adalah 43 persen dan 29 persen. Hasil dari survey yang dilakukan secara online ini dapat 
INTEGRITAS : Jurnal Pengabdian

Vol 4, No 1, Juli 2020

ISSN $2580-7978$ (cetak) ISSN 2615 - 0794 (online)

ditarik kesimpulan awal bahwa masih banyak mahasiswa di kota Palembang memiliki tingkat literasi keuangan yang rendah. Fenomena ini perlu diselesaikan. Salah satu cara yang efektif adalah melakukan pelatihan literasi keuangan bagi mahasiswa di Kota Palembang.

\section{METODE PELAKSANAAN}

\section{Analisa dan Solusi Permasalahan}

Hasil survey kepada masyarakat, khususnya mahasiwa terkait tingkat literasi yang rendah, perlu untuk dicari solusinya. Apalagi mahasiswa yang nantinya akan menjadi salah satu pemeran utama dalam mendukung aktivitas ekonomi di masa depan. Pada saatnya nanti, mereka akan membuat keputusan-keputusan keuangan baik dalam skala individu, keluarga, perusahaan dan yang lebih luas seperti negara. Pengetahuan dasar literasi keuangan ini penting sebagai fondasi awal agar peserta dapat mengetahui dan mengimplrementasikan konsep dasar terkait inflasi, suku bunga dan diversifikasi risiko.

Berdasarknan penjelasan di atas, sekaligus untuk mendorong pemerintah guna mencapai tingkat literasi masyarakat Indonesia sebesar 75 persen pada akhir tahun 2019, maka pengabdian masyarakat tentang Edukasi Literasi Keuangan bagi Mahasiswa di kota Palembang ini penting untuk dilakukan. Kegiatan ini diharapkan mampu memberikan pemahaman baru atau tambahan pengetahun seputar literasi keuangan bagi mahasiwa.

\section{Tindak Lanjut setelah Pengabdian}

Tindak lanjut setelah melakukan edukasi literasi keuangan bagi mahasiswa di Palembang adalah mendorong mereka untuk mengimplementasikan ilmu yang sudah dipelajari dengan cara mulai melakukan investasi sejak dini. Saat ini, beberapa lembaga keuangan sudah memberikan kemudahan akses bagi masyarakat untuk mulai investasi denga dana awal yang relatif terjangkau. Investasi tidak hanya memberikan kesempatan masyarakat untuk mendapatkan 
INTEGRITAS : Jurnal Pengabdian

Vol 4, No 1, Juli 2020

ISSN 2580 - 7978 (cetak) ISSN 2615 - 0794 (online)

imbal hasil tapi juga harus belajar tentang mengelola risiko. Proses belajar melalui praktek langsung akan memberikan kemudahan agar mereka terus belajar.

\section{Persiapan Pelaksanaan Pengabdian}

Sebelum kegiatan pengabdian pada masyarakat dilakukan perlu adanya persiapan yang harus dilakukan terlebih dahulu seperti:

1. Melakukan diskusi dengan panitia yang terlibat serta menentukan target dan jumlah mahasiswa.

2. Menetapkan hari, tanggal kegiatan, tempat serta peralatan yang perlu dipersiapkan untuk pelaksanaan kegiatan pelatihan tersebut. Persiapan yang dilakukan untuk pelaksanaan kegiatan tersebut adalah menyediakan ruang pelatihan beserta peralatan pendukung seperti laptop, proyektor dan lain-lain.

3. Mempersiapkan materi pelatihan dalam bentuk modul yang akan disampaikan kepada peserta. Membuat akun Google Drive yang akan digunakan untuk menyimpan materi pelatihan yang nantinya bisa diakses oleh peserta pelatihan.

4. Memastikan bahwa peserta memahami materi yang disampaikan dengan melihat hasil survey literasi keuangan.

5. Setelah persiapan selesai, ditetapkan waktu pelaksanaan pengabdian masyarakat.

\section{Pelaksanaan Pengabdian}

Pelaksanaan pengabdian dimulai dengan memberikan informasi terkait manfaat dan pentingnya literasi keuangan bagi mahasiswa. Pada sesi ini, pemateri mengambil contoh dari beberapa jurnal dan artikel baik dari dalam dan luar negeri. Tahapan selanjutnya adalah penyampaian materi tentang inflasi dan pentingnya manajemen keuangan agar daya beli dari uang yang dimiliki tidak mengalami penurunan akibat inflasi yang terjadi. Materi dilanjutkan dengan pemahaman tentang suku bunga dan diversifikasi risiko. Subjek ini menjadi 
penting untuk memitigasi risiko akibat kesalahan pada manajemen portofolio investasi yang dimiliki. Urutan saat pelatihan yaitu pembukaan yang disampaikan oleh ketua pelaksana dan dilanjutkan dengan penyampaian materi literasi keuangan bagi mahasiswa dan diakhiri dengan sesi tanya jawab serta pembagian pelakat.

Tabel 1. Jadwal Edukasi Literasi Keuangan

\begin{tabular}{|c|c|c|}
\hline Tanggal & Waktu & Materi \\
\hline 4 April 2020 & $09: 00-12: 00$ & $\begin{array}{llll}\text { Literasi } & \text { Keuangan } & \text { (Inflasi, Numerasi, } \\
\text { Bunga } & \text { Majemuk dan Diversifikasi } \\
\text { Risiko) } & & & \end{array}$ \\
\hline 4 April 2020 & $14: 00-16: 30$ & $\begin{array}{llll}\text { Literasi } & \text { Keuangan } & \text { (Inflasi, Numerasi, } \\
\text { Bunga } & \text { Majemuk } & \text { dan Diversifikasi } \\
\text { Risiko) } & & & \end{array}$ \\
\hline 18 April 2020 & $09: 00-12: 00$ & $\begin{array}{llll}\text { Literasi } & \text { Keuangan } & \text { (Inflasi, Numerasi, } \\
\text { Bunga } & \text { Majemuk dan Diversifikasi } \\
\text { Risiko) } & & & \end{array}$ \\
\hline 18 April 2020 & $14: 00-16: 30$ & $\begin{array}{llll}\text { Literasi } & \text { Keuangan } & \text { (Inflasi, Numerasi, } \\
\text { Bunga } & \text { Majemuk } & \text { dan Diversifikasi } \\
\text { Risiko) } & & & \end{array}$ \\
\hline
\end{tabular}

\section{HASIL DAN PEMBAHASAN}

\section{Hasil Pengabdian}

Berdasarkan wawancara, tanya jawab dan pengamatan langsung selama kegiatan berlangsung, pengabdian masyarakat terkait literasi keuangan ini memberikan hasil sebagai berikut :

- Memberikan pemahaman dan informasi baru bagi mahasiswa untuk tahu tentang pentingnya literasi keuangan bagi kebutuhan keuangan masa depan.

- Peserta berkomitmen untuk mulai melakukan investasi sejak dini, dimulai dengan membuka akun saham di perusahaan sekuritas di kota Palembang dengan saldo minimal Rp.100.000,-- 
INTEGRITAS : Jurnal Pengabdian

Vol 4, No 1, Juli 2020

ISSN $2580-7978$ (cetak) ISSN 2615 - 0794 (online)

\section{Pembahasan Pengabdian}

Selama kegiatan pengabdian berlangsung, ada beberapa faktor pendukung terlaksananya pengabdian kepada masyarakat ini antara tingginya antusiasme peserta dengan materi yang disampaikan, khususnya pengetahuan tentang bunga majemuk (compound interest). Peserta yang hadir secara total mencapai 115 orang, angka ini lebih tinggi dibandingkan target yang direncanakan yaitu sebanyak 100 mahasiswa. Kegiatan ini dilakukan di dua tempat yang berbeda yaitu Univesitas UIN Raden Fatah Palembang dan Kafe Kenanga Palembang.

Faktor penghambat saat kegiatan berlangsung yaitu pendingin ruangan di Kafe Kenanga tidak semuanya berfungsi, sehingga saat penyampaian materi ada beberapa peserta yang merasa tidak nyaman. Selain itu, jumlah peserta yang melebihi target juga menyebabkan beberapa peserta tidak mendapat kesempatan untuk melakukan diskusi. Hambatan tersebut diatasi dengan mengupload materi ke dalam Google Drive yang bisa diakses oleh peserta dan membuat forum diskusi melalui grup WhatsApp agar diskusi antar peserta tetap dalam dilakukan. 

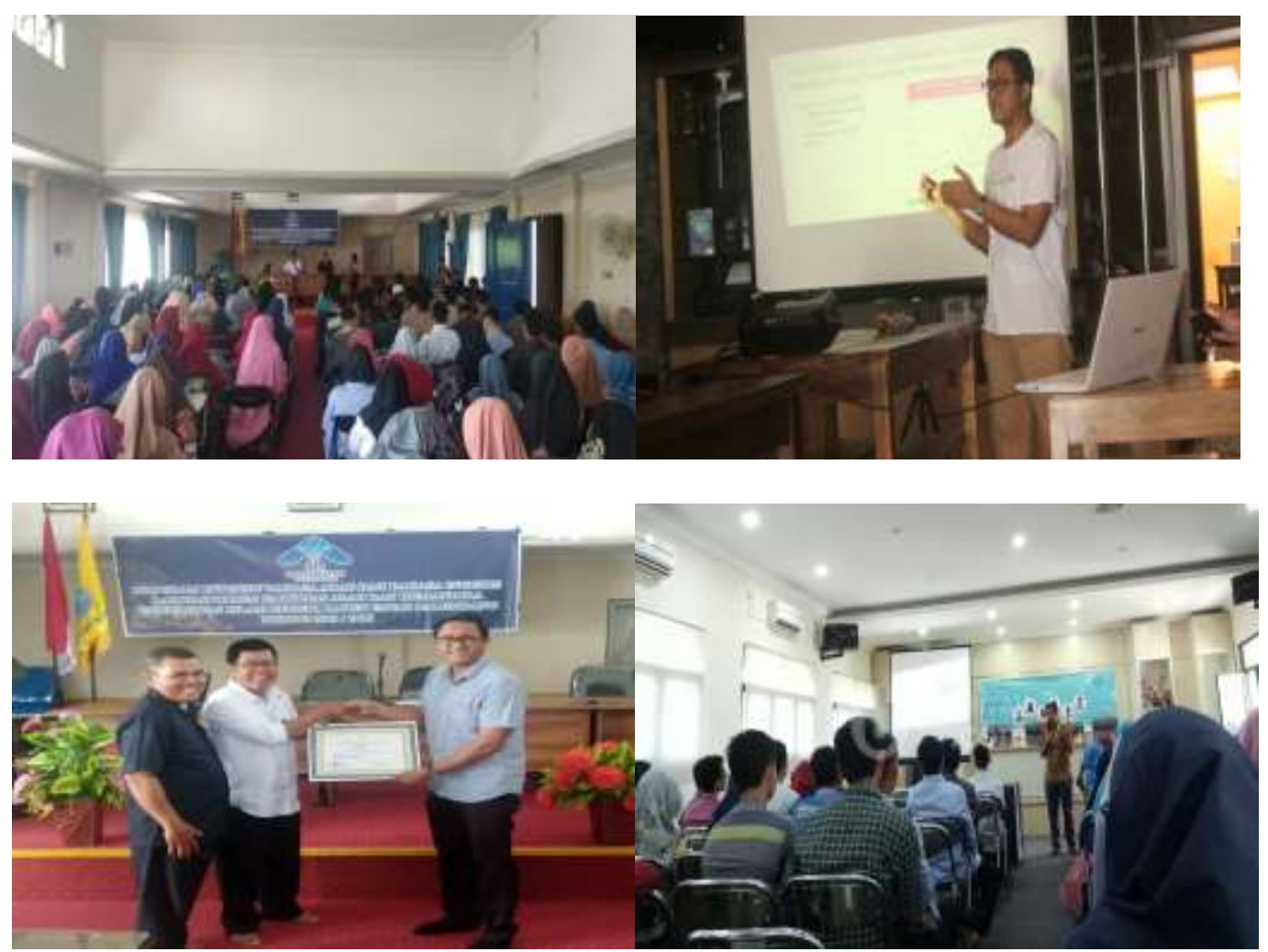

Gambar 1. Suasana Pelatihan

\section{KESIMPULAN}

\section{Kesimpulan Pengabdian}

Berdasarkan hasil pelaksanaan kegiatan pengabdian pada masyarakat yang telah dilakukan, dapat ditarik beberapa kesimpulan antara lain :

1. Proses kegiatan pengabdian kepada masyarakat dengan tema Edukasi Literasi Keuangan bagi Mahasiswa di kota Palembang berjalan dengan lancar. Peserta yang hadir sebanyak 115 orang yang mewakili beberapa universitas di kota Palembang.

2. Peserta yang hadir dan mengikuti workshop edukasi ini juga sudah mengisi kembali survey literasi keuangan dan hasilnya jauh lebih baik dibandingkan sebelum mengikuti pelatihan 
INTEGRITAS : Jurnal Pengabdian

Vol 4, No 1, Juli 2020

ISSN 2580 - 7978 (cetak) ISSN 2615 - 0794 (online)

3. Saat proses edukasi berlangsung, penulis juga memberikan beberapa contoh produk investasi yang ada di Indonesia lengkap dengan tingkat imbal hasil selama 10 tahun terakhir.

\section{UCAPAN TERIMA KASIH}

Ucapan terima kasih kami sampaikan kepada pihak-pihak yang sudah terlibat dalam mensukseskan kegiatan pada masyarakat tentang edukasi literasi keuangan bagi mahasiswa di kota Palembang, antara lain :

1. Universitas IGM, Bapak Dr. Marzuki Alie, S.E., M.M

2. Dekan Fakultas Ekonomi, ibu Endah Dewi Purnamasari, S.E., M.M

3. Rekan-rekan dosen di Fakultas Ekonomi Universitas IGM

4. Organisasi Kemahasiswaan Fakultas Ekonomi Universitas IGM

5. Para mahasswa yang turut membantu sebagai tim pelaksana

\section{DAFTAR PUSTAKA}

Klapper, L., Lusardi, A. \& Panos, G.A. (2013). Financial Literacy and Its Consequences from Russia during the Financial Crisis. Journal of Banking \& Finance 37 (2013) 3904-3923

Lusardi, A. (2019). Financial Literacy and the Need for Financial Education: Evidence and Implications. Swiss Journal of Economics and Statistics (2019) $155: 1$

Oseifuah, E., Gyekye, A. \& Formadi, P. (2018). Financial Literacy among Undergraduate Students: Empirical Evidence from Ghana. Academy of Accounting and Financial Studies Journal, Volume 22, Issue 6, 2018

Ozturk, I. (2008). The Role of Education in Economic Development: A Theoritical Perspective. Journal of Rural Development and Administration, Volume XXXIII, No. 1, pp 39-47

Wann, C.R. (2016). The Impact of Teaching Financial Literacy to Collage Students. Journal of Economics and Finance Education. 